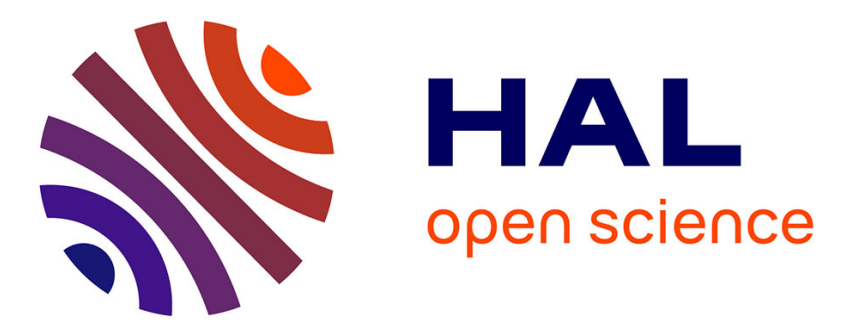

\title{
Pigeon odor varies with experimental exposure to trace metal pollution
}

\author{
Sarah Leclaire, Marion Chatelain, Anaïs Pessato, Bruno Buatois, Adrien \\ Frantz, Julien Gasparini
}

\section{- To cite this version:}

Sarah Leclaire, Marion Chatelain, Anaïs Pessato, Bruno Buatois, Adrien Frantz, et al.. Pigeon odor varies with experimental exposure to trace metal pollution. Ecotoxicology, 2019, 28 (1), pp.76-85. 10.1007/s10646-018-2001-x . hal-02337484

\section{HAL Id: hal-02337484 https://hal.sorbonne-universite.fr/hal-02337484}

Submitted on 29 Oct 2019

HAL is a multi-disciplinary open access archive for the deposit and dissemination of scientific research documents, whether they are published or not. The documents may come from teaching and research institutions in France or abroad, or from public or private research centers.
L'archive ouverte pluridisciplinaire HAL, est destinée au dépôt et à la diffusion de documents scientifiques de niveau recherche, publiés ou non, émanant des établissements d'enseignement et de recherche français ou étrangers, des laboratoires publics ou privés. 
3 Sarah LECLAIRE ${ }^{1,2,3}$, Marion CHATELAIN ${ }^{3, *}$, Anaïs PESSATO ${ }^{2,5, \dagger}$, Bruno BUATOIS $^{2}$, $4 \quad$ Adrien FRANTZ ${ }^{3}$, Julien GASPARINI ${ }^{3}$

$5 \quad{ }^{1}$ Laboratoire Evolution \& Diversité Biologique, UMR 5174 (CNRS, Université Paul Sabatier, 6 ENFA), 118 route de Narbonne, 31062 Toulouse, France.

$7 \quad{ }^{2}$ Centre d'Ecologie Fonctionnelle et Evolutive (CEFE), UMR 5175, CNRS - Université de 8 Montpellier - Université Paul Valéry Montpellier - EPHE, 1919 route de Mende, 34293 9 Montpellier, France

${ }^{3}$ Sorbonne Université, UPEC, Paris 7, CNRS, INRA, IRD, Institut d'Ecologie et des Sciences de l'Environnement de Paris, 75005 Paris, France

*Current address: Wild Urban Evolution and Ecology Lab, Center of New Technologies, University of Warsaw, Banacha 2C, 02-097 Warsaw, Poland

$14{ }^{\dagger}$ Current address: Centre for Integrative Ecology, Deakin University, Geelong Waurn Ponds Campus, Victoria 3217, Australia

Corresponding author: Sarah Leclaire, sarah.leclaire@free.fr; tel: +33 05615567 53;

ORCID: 0000-0002-4579-5850 
Trace metals are chemical pollutants that have well-known noxious effects on wildlife and that are current major environmental issues in urban habitats. Previous studies have demonstrated their negative (e.g. lead) or positive (e.g. zinc) effects on body condition, immunity and reproductive success. Because of their effects on condition, trace metals are likely to influence the production of condition-dependent ornaments. The last decade has revealed that bird odors, like mammal odors, can convey information on individual quality and might be used as secondary sexual ornaments. Here, we used solid-phase microextraction headspace sampling with gas chromatography - mass spectrometry to investigate whether plumage scent varied with experimental supplementation in lead and/or zinc in feral pigeons. Zinc supplementation (alone or in combination with lead) changed the proportion of several volatiles, including an increase in the proportion of hydroxy-esters. The production of these esters, that most likely originate from preen gland secretions, may be costly and might thus be reduced by stress induced by zinc deficiency. Although lead is known to negatively impact pigeon condition, it did not statistically affect feather scent, despite most of the volatiles that increased with zinc exposure tended to be decreased in lead-supplemented pigeons. Further studies should evaluate the functions of plumage volatiles to predict how trace metals can impact bird fitness.

Keywords: Scent; Zinc; Lead; Birds; Dove 


\section{Introduction}

Trace metals (e.g. lead, iron, copper, zinc) are normally present in very low levels in the environment and small amounts are essential part of physiology in animals and plants (Powell 2000, Prasad 2009, Plum et al. 2010). For instance, zinc is essential in regulating homeostasis, immune responses, and oxidative stress (Stefanidou et al. 2006), and zinc deficiency has serious consequences that have been recognized for many years and that include oxidative damages, diabetes and congenital malformations (Fosmire 1990; Oteiza et al. 1995; Prasad 2003). However, excessive quantities of trace metals can be toxic. The large amount of trace metals that have been released in the environment by anthropogenic activities (Nriagu 1979) have well-known noxious effects on humans (Järup 2003; Tchounwou et al. 2012) and wildlife (Demayo et al. 1982; Goutte et al. 2014; Scheuhammer et al. 2007). The binding potential (Godwin 2001; Tainer et al. 1992) and the propensity of trace metals to catalyze oxidation reactions (Koivula and Eeva 2010) are responsible for immunosuppression (Chatelain et al. 2016c; Snoeijs et al. 2005; Snoeijs et al. 2004), oxidative stress (Berglund et al. 2007) and endocrine disruptive effects (Baos et al. 2006; Meillère et al. 2016). For instance, lead, whose widespread use has caused extensive environmental contamination (Nriagu 1996), is associated with impaired learning in herring gulls (Larus argentatus) (Burger and Gochfeld 2005), reduced sperm quality in red deer (Cervus elaphus) (Castellanos et al. 2015), and higher oxidative stress in Mozambique tilapias (Oreochromis mossambicus) (Kaya and Akbulut 2015).

Sexual ornaments are conspicuous phenotypic traits that can take various forms such as large antlers, bright plumage, or elaborated song, and that are displayed to attract mates. Because their expression can be influenced by genotype and environment, including various stress factors, such as food availability, extreme temperatures, noise and parasites (McGraw et al. 2002; Troïanowski et al. 2017; von Schantz et al. 1999), they often honestly reveal the 
quality of the bearer (Zahavi and Zahavi 1999). By inducing physiological stress, trace metals can also alter ornament expression, as shown for the plumage coloration and singing behaviour of birds (Chatelain et al. 2017; Giraudeau et al. 2015; Gorissen et al. 2005; Vallverdú-Coll et al. 2015). Odor cues are also subjected to physiological and environmental influences (Ferkin et al. 1997; Johnston and Bronson 1982; Penn and Potts 1998), and are major secondary sexual traits in a wide range of species (Blaustein 1981; Havlicek et al. 2005; Martín and López 2006; Wyatt 2014). However, the effects of environmental pollution on their expression are largely unknown.

In this study, we tested the hypothesis of the impact of trace metals exposure (zinc and lead) on plumage odor in feral pigeon (Columbia livia) by an experimental supplementation approach. Although birds have long been considered to rely primarily on visual and acoustic cues, the past decade has revealed that birds use olfaction in various contexts including mate choice or parental care (reviewed in Caro et al. 2015). Bird odors, like mammal odors, can vary with genotype (Leclaire et al. 2014b), sex-hormone levels (Whittaker et al. 2017) and diet (Thomas et al. 2010), and are mainly composed of alkanes, alkanols, esters and fatty acids (reviewed in Campagna et al. 2012) that may be energetically costly to produce. Using a similar experimental design, we have already described beneficial effects of zinc on body mass, immunity and female investment into eggs (Chatelain et al. 2016b; Chatelain et al. 2016c), and detrimental effects of lead on iridescent coloration, the maternal transfer of antibodies into eggs and nestling growth (Chatelain et al. 2016b; Chatelain et al. 2017). We predict therefore that if pigeon odor is condition-dependent, it should vary in opposite direction with experimental exposure to lead and zinc.

\section{Material and methods}

Capture and housing 
From February 20 to March 27 2013, we captured 96 free-living adult feral pigeons in several locations in Paris. We immediately transferred them in 8 outdoor aviaries $(2.20 \mathrm{~m} \times 2.20 \mathrm{~m})$ at the CEREEP field station (Centre d'Ecologie Expérimentale et Prédictive - Ecotron Ile-deFrance, UMS 3194, Ecole Normal Supérieure, Saint-Pierre-lès-Nemours, France).

\section{Metal supplementation}

This study is part of a bigger study investigating the effect of zinc and lead on several life history traits of pigeons. Details on the protocol have thus been published elsewhere (Chatelain et al. 2016b; Chatelain et al. 2016c; Chatelain et al. 2017). Briefly, on April 8 2013, after an acclimation period, aviaries were divided into 4 metal treatments ( 2 aviaries per treatment). Birds were evenly distributed among aviaries according to their flock, sex and plumage eumelanin level (Chatelain et al. 2016b). Treatments were lead supplementation (tap water enriched with $1 \mathrm{ppm}$ lead acetate), zinc supplementation (tap water enriched with 10 ppm zinc sulphate), lead and zinc supplementation (tap water enriched with 1 ppm lead acetate and $10 \mathrm{ppm}$ zinc sulphate) and no supplementation, i.e. control (tap water with no metal added). We chose these concentrations based on the lead concentration measured in blood of urban birds (Roux and Marra 2007) and on the gastrointestinal absorption rate of lead in zebra finches (Dauwe et al. 2002). Zinc concentrations were approximated using the zinc/lead concentration ratio measured in the environment and in bird feathers (on average, zinc is 10 times more concentrated than lead; Azimi et al. 2005; Chatelain et al. 2014; Frantz et al. 2012). Drinking bowls and baths were filled every other day with treated water. The efficiency of our supplementation protocol to increase bird exposure to lead and zinc has been previously validated (Chatelain et al. 2016b).

\section{Sample collection}


After 20 weeks of treatment, a few feathers $(\sim 33 \mathrm{mg})$ were cut in the lower back region of 74 birds (37 males and 37 females), and stored in 4 ml PTFE-faced septum sealed glass vials at $80^{\circ} \mathrm{C}$ until analysis. Birds from five aviaries (two lead-supplemented aviaries, one zincsupplemented aviary, one zinc-and-lead-supplemented aviary and one control aviary) were sampled on 27 August 2013, while birds from the remaining three aviaries (one zincsupplemented, one zinc-and-lead supplemented and one control aviaries) were sampled on the next day. The 74 birds sampled included 20 control birds, 19 lead-supplemented birds, 17 zinc-supplemented birds and 18 zinc-and-lead-supplemented birds.

\section{Chemical analyses}

We extracted chemical compounds with solid phase microextraction (SPME) using a

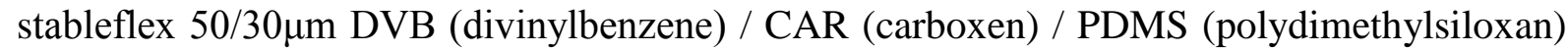
fiber (Supelco, Sigma-Aldrich, Bellefonte, PA, USA). To clear headspace for SPME extraction, we packed feathers at the bottom of the vial, using a glass rod cleaned with dichloromethane and ethanol between samples. The sample was then placed for $20 \mathrm{~min}$ in a laboratory incubator maintained at $34^{\circ} \mathrm{C}$. We chose $34^{\circ} \mathrm{C}$ to mimic the natural temperature of bird body surface during a Parisian summer. During the summer 2013, the average daily maximal temperature in Paris was $25.3^{\circ} \mathrm{C}$ (public data of Meteo France). At $25^{\circ} \mathrm{C}$ ambient temperature and low humidity, surface temperature of birds is $33.4^{\circ} \mathrm{C}$ (Chilgren and King 1973). The SPME fiber was then exposed to the headspace (without touching the feathers) for 25 minutes at $34^{\circ} \mathrm{C}$, after which the fiber was retracted and the adsorbed chemicals were analyzed by gas chromatography-mass spectrometry (GC-MS). Only one SPME fiber was used in the study.

We analyzed the samples using a Shimadzu GCMS-QP2010plus (Shimadzu Scientific Instruments, Kyoto, Japan) equipped with an Optima®-5MS column (30 m x 0.25 mm x 0.25 
$\mu \mathrm{m}$, Macherey-Nagel, Düren, Germany) at the Plateforme d'Analyses Chimiques en Ecologie (PACE), technical facilities of the LABoratoire d'Excellence named Centre Méditerranéen de l'Environnement et de la Biodiversité (CEMEB). Helium was used as the carrier gas, at a constant $1 \mathrm{ml} / \mathrm{min}$ flow rate. Fibers were exposed in a $200{ }^{\circ} \mathrm{C}$ injection port to desorb volatiles. We ran the following temperature protocol: $40^{\circ}$ for $5 \mathrm{~min}, 40^{\circ} \mathrm{C}$ to $180^{\circ} \mathrm{C}$ ramped at $5^{\circ} \mathrm{C} / \mathrm{min}$, $180^{\circ} \mathrm{C}$ to $250^{\circ} \mathrm{C}$ ramped at $10^{\circ} \mathrm{C} / \mathrm{min}$, and finally held at $250^{\circ} \mathrm{C}$ for $1 \mathrm{~min}$. The ion source and transfer line temperatures was $200^{\circ} \mathrm{C}$ and $250^{\circ} \mathrm{C}$ respectively. Mass were scanned from 38 $350 \mathrm{~m} / \mathrm{z}$ in electron ionization mode. Fibers were removed from the injection port after 10 min of desorption. We regularly interspersed blanks throughout the sample analyses to detect contamination. We ran an alkane standard solution (Alkanes standard solution, 04070, Sigma Aldrich ${ }^{\circledR}$, Germany) under the same conditions for retention index calculation. The samples from 9 controls, 9 lead-supplemented pigeons, 10 zinc-supplemented birds and 11 zinc-andlead-supplemented birds were ran in March 2015, while the other samples were ran in June 2015. Within each analysis time period (March vs. June 2015), samples were ran randomly. Consequently, there was no difference in date of analysis between zinc-supplemented and non-zinc supplemented samples or between lead-supplemented and non-lead supplemented samples (all P > 0.15). Ten samples had very low GCMS signal and were not included in the statistical analyses.

To confirm that the feather odor captured from captive pigeons was representative of that of wild pigeons, we compared the chromatograms with those of two samples of back feathers collected just after capture in February 2013. In addition, to shed light on the potential origin of plumage chemicals, we compared the feather profiles to those of preen secretion samples collected on two pigeons just after capture.

Chromatograms were analyzed blind to treatment using the Shimadzu GC-MS Solution software. Analytes were identified by comparison of mass spectral data using the 
NIST library 2011 and cross-checking linear retention index of the spectral match found in the literature (PubChem database) with the calculated linear retention index of the analytes. Four monoterpenes were detected in pigeon feathers ( $\alpha$-Pinene, $\beta$-Pinene, p-Cymene and Bornyl acetate; Table 1). Most probably of plant origin (Charpentier et al. 2012), they were excluded from the analyses. One peak corresponded to a co-elution of several compounds including one contaminant (Table 1), and it was also not included in the analyses.

To ascertain that our GCMS analyses were repeatable, 5 samples were analyzed twice with a few days interval (range: 5 - 8 days). Results show that total chromatogram area was lower in the second analysis than in the first analysis (paired t-test: $\mathrm{t}_{4}=5.32, \mathrm{P}=0.006$ ) but that the composition of the two samples from the same bird was repeatable (PERMANOVA analyses with bird identity as fixed factor: $\left.\mathrm{F}_{4,4}=8.93, \mathrm{P}=0.001\right)$.

\section{Statistical analyses}

Because, for most samples, we did not control for the amount of feathers collected, and because an internal standard was not included in the GCMS analyses, we did not rely on the absolute abundance of chromatogram peaks for the analyses of chemical composition; rather, we quantified each peak as the proportion of the peak size relative to the total area of the chromatogram. Proportions of chemical compounds were then transformed using isometric log ratio "ilr" (Brückner and Heethoff 2017). In addition, to limit the effect of the differences in the amount of feathers on odor composition, we restricted the odor composition analyses on the peaks that each represented on average more than $0.75 \%$ of the chromatogram ( $n=19$ peaks representing on average $91.0 \% \pm 0.3 \%$ of the total chromatogram areas, Table 1). All of these peaks, except one, were present in all birds.

To determine if the chemical composition of plumage odor was related to lead and zinc exposition, we used a PERMANOVA with 5000 permutations i.e. nonparametric 
multivariate analysis of variance, (Adonis2 function, "vegan" package in R; Oksanen et al. 2013), based on Euclidean distance. The two-way interaction between lead and zinc, the bird sex and the analysis time period (March vs. June 2015) were also included in the model. The date of feather sampling was used as strata, thus restricting permutations within date of sampling. In Adonis, significant differences may be caused by different within-group dispersion instead of different mean values of the groups (Warton et al. 2012). For significant effects, we therefore tested difference in dispersion between groups (Betadisper function, "vegan" package; Oksanen et al. 2013).

To determine the chemical compounds that were preferentially associated with a significant fixed effect, we used correlation indices (function "multipatt" in the "indicspecies" package in R; De Caceres et al. 2016) with the point biserial coefficient of association on proportions of chemical compounds (De Cáceres and Legendre 2009). We restricted permutations within date of sampling. This method uses permutation tests to test significance of value, but does not correct for multiple tests. Multiple testing corrections are flawed because they assume multiple tests are independent, whereas multiple volatiles can show correlated effects (Fig. S1) because of the nature of the data (relative abundance vs. absolute abundance) and because the biosynthesis pathway of these volatiles may be related. Therefore, we also performed robust principal component analyses (RPCA) on the ilrtransformed dataset (Filzmoser et al. 2009) to identify the subset of compounds that varied with treatment. RPCA axis scores were compared between zinc-supplemented and non-zinc supplemented birds using linear mixed models with zinc treatment and analysis time period as fixed effects, and date of feather sampling as a random factor.

We performed all statistical analyses using the $\mathrm{R}$ statistical software (R Core Team 2017) and used a significance level set at $\alpha=0.05$. 


\section{Results}

216

217

We detected a total of 45 peaks in the 63 odor profiles of pigeons, that included alkanes, aldehydes, alcohols, ketones, and esters (Table 1 and Fig. 1). Only 6 (13\%) of these compounds were also detected in preen secretions (Table 1). In contrast, 39 of them (87\%) were also detected in the plumage of wild Parisian pigeons, suggesting that captivity had only slight influence on the identity of feather volatiles.

Chemical composition varied with zinc supplementation $\left(\mathrm{F}_{1,61}=4.27, \mathrm{P}=\right.$ 0.016; Fig. 2 and Fig. S2), but not with lead supplementation $\left(\mathrm{F}_{1,60}=0.62, \mathrm{P}=0.89\right)$ or the interaction between zinc and lead $\left(\mathrm{F}_{1,59}=1.22, \mathrm{P}=0.56\right)$. It did not vary with sex $\left(\mathrm{F}_{1,60}=0.14\right.$, $\mathrm{P}=0.99)$, but varied with the period when the samples were analyzed $\left(\mathrm{F}_{1,61}=13.20, \mathrm{P}<\right.$ 0.001). Multivariate dispersion in chemical composition between zinc-supplemented and nonzinc supplemented birds was similar $\left(\mathrm{F}_{1,62}=0.59, \mathrm{P}=0.45\right)$. Correlation indices showed that the proportions of the two hydroxy esters and 3-Hexanone were increased in zinc supplemented birds, while the proportion of Nonanal was reduced (Fig. 3). Similarly, a robust PCA showed that the second principal component, which accounted for $26 \%$ of the variance and which was positively related to the two hydroxy esters and the two ketones, was higher in zinc-supplemented birds than in non-zinc supplemented birds $\left(\chi^{2}{ }_{1}=7.14, \mathrm{P}=0.008\right.$; Fig. 4$)$.

\section{Discussion}

By analyzing feather volatiles of feral pigeons chronically exposed to zinc and/or lead, we provide evidence for an effect of zinc on pigeon odor composition. In particular, we found that zinc mainly increased the relative abundance of the two hydroxy esters and 3-Hexanone. All the compounds affected by zinc supplementation may potentially be produced endogenously by the bird. However, in contrast to several species, where most plumage 
chemicals originate from the preen gland (Leclaire et al. 2011; Mardon et al. 2011; Zhang et al. 2009), only the two hydroxy-esters were detected in pigeons' preen secretions. Although the sample size used to study the difference between preen secretion and feather volatiles was low ( $\mathrm{n}=2$ birds sampled for preen secretions), this result is consistent with a study on common wood pigeons (Columba palumbus), where $93 \%$ of the whole plumage lipids do not originate from preen secretions (Jacob and Grimmer 1975).

The other compounds affected by zinc exposure were not detected in preen secretions, and may rather originate from other lipid-producing areas in the integument (Jacob and Ziswiler 1982) or from feather bacteria metabolism (Whittaker and Theis 2016). The role of bacteria in animal olfactory signaling has recently received renewed interests (Archie and Theis 2011; Douglas and Dobson 2013; Ezenwa and Williams 2014) and a few experimental studies in mice, elephants (Loxodonta africana), Indian mongooses (Herpestes auropunctatus) and European hoopoes (Upupa epops) have shown that some major odorants require commensal bacteria for their production (Goodwin et al. 2016; Gorman et al. 1974; Li et al. 2013; Martin-Vivaldi et al. 2010). Methyl-branched alkanes, methyl ketones, and aldehydes can all be released by bacterial degradation of fatty acids (Schulz and Dickschat 2007). Feathers of zinc-supplemented pigeons have lower bacterial load and different bacterial assemblage than feathers of birds non-exposed to zinc (Chatelain et al. 2016a), which may have led to differences in the composition of feather volatiles between birds. Further studies on the mechanisms of avian odor production are clearly needed to understand how environment can affect feather volatiles.

We found that zinc increased the proportion of preen-gland-related compounds, which might suggest higher production of preen oil in zinc-exposed birds. Several studies have suggested that birds in higher condition are able to produce higher quantity of preen oil. For instance, experimental infections and immune challenge reduce the size of the preen gland in 
house sparrows (Passer domesticus) and tawny owls (Strix aluco) (Moreno - Rueda 2015;

Pap et al. 2013; Piault et al. 2008). Zinc provided at low dose is essential for many biological processes (Stefanidou et al. 2006), and accordingly, zinc supplementation has various beneficial effects on pigeon condition (Chatelain et al. 2016b; Chatelain et al. 2016c). Therefore, zinc, through its positive effects on bird condition, may increased the ability of bird to produce wax esters and other costly volatiles. Although avian odors have reapeatedly been shown to vary with genetics (i.e., Krause et al. 2012; Leclaire et al. 2017) and physiological status (Douglas et al. 2008; Whittaker et al. 2018), a very few studies have shown the effect of environmental stressors on their expression (Bombail et al. 2018). For instance, infection influences the wax ester profiles of preen oil in song sparrows (Melospiza melodia) and the volatile profiles of feces in mallards (Anas platyrhynchos) (Grieves et al. 2018; Kimball et al. 2013). Our study, which shows that the volatile profiles of feather is related to zinc levels in the environment, is therefore consistent with the stress-induced effects on odors demonstrated in other birds.

In several avian species, odor plays a crucial role in social interactions (Balthazart and Schoffeniels 1979; Balthazart and Taziaux 2009; Hirao et al. 2009). Zinc-induced changes in pigeon scent might therefore influence the behavior of conspecifics, with, for instance, females avoiding the scent of zinc-deficient males. However, although pigeons are wellknown to use their olfactory abilities for homing (reviewed in Wallraff 2005), it is unknown whether they use also olfaction for social communication. Feather chemicals may play also a role in social communication by affecting feather coloration or condition (Moreno - Rueda 2017). For instance, in house finches (Carpodacus mexicanus), preen oil enhances the coloration of red feathers (López-Rull et al. 2010). In pigeons, changes in the coloration of melanic feathers have been induced by zinc supplementation (Chatelain et al. 2017), and might therefore be mediated by changes in the chemical composition of feather volatiles. 
Feather chemicals do not only play a role in social communication; they can protect feathers from wear and act as chemical defenses against parasites (Douglas 2013; Hagelin and Jones 2007). For instance, in rock pigeons, preen oil has positive effects on plumage condition (Moyer et al. 2003). 3-Hexanone, which was increased in zinc-exposed birds, is a common urine component of mammals, including humans (Burger et al. 2006; delBarco - Trillo et al. 2011; Raymer et al. 1986; Smith et al. 2008), and has been detected in the feathers of white Leghorn chickens (Gallus gallus domesticus L.) (Bernier et al. 2008) and king penguins (Gabirot et al. 2018). It belongs to the volatile methyl-ketone family, whose some compounds can provide protection against parasites (Borges et al. 2015; Kirillov et al. 2017). According to the parasite-repellent function of volatile ketones, volatile methyl-ketones of dark-eyed juncos (Junco hyemalis) are increased during the breeding season (Soini et al. 2007), when the need for protection against nest parasites is high. Zinc, by inducing higher production of hydroxy-esters and 3-hexanone, might thus enhance plumage condition and the anti-parasite properties of feathers, thus adding to the numerous positive effects of zinc on pigeon (Chatelain et al. 2016b; Chatelain et al. 2016c).

Lead is a toxic trace metal that can impair various biological processes, leading to illness and mortality (Papanikolaou et al. 2005). In feral pigeons, lead decreases iridescent coloration, the maternal transfer of antibodies into eggs, and nestling growth (Chatelain et al. 2016b; Chatelain et al. 2017). Despite these detrimental effects on pigeon condition, we did not detect effects of lead on pigeon scent. As our experimental exposure to lead underestimated the natural range (lead was 1.5 times less concentrated in the feathers of leadsupplemented pigeons than in those of wild feral pigeons; Chatelain et al. 2016b), we cannot exclude that, in urban areas, the high concentration of lead negatively impacts odor production in birds. 

kept in captivity. Similarly, no sex-differences in preen secretion composition have been detected in non-breeding rock pigeons (Montalti et al. 2005). Although sexual dimorphism in chemical cues from feathers or preen secretions has been reported in several bird species (Amo et al. 2012; Leclaire et al. 2011; Whittaker et al. 2010; Zhang et al. 2010), it is not ubiquitous. For instance, king penguins (Aptenodites patagonicus) and Cory's shearwaters (Calonectris borealis) seem to exhibit no sex-differences in scent (Gabirot et al. 2018; Gabirot et al. 2016). Pigeons display sexual polymorphism in iridescent coloration of neck feathers (Chatelain et al. 2017; Leclaire et al. 2014a), and might, therefore, use this other trait to discriminate between sexes. Alternatively, because the molecules detected using GC-MS depend on the analysis strategy (e.g., extraction protocol and GC column), the profile of chemical composition presented here is not exhaustive. For instance, carboxylic acids, which are better resolved using a polar column (Whelan et al. 2010), might encode sex information. changes in the feather volatile composition of feral pigeons. Future studies should now evaluate the role of these volatiles in social communication, protection against parasites or feather wear to further predict how trace metals, which are chemical pollutants of prime concern in cities, can impact bird fitness.

\section{Acknowledgements}

We thank the "Mairie de Paris" (Thomas Charachon) for allowing the capture of birds and the Centre de Recherche en Ecologie Experimentale et Predictive (CEREEP) which provided logistic support for the field work of this study. We are very thankful to T. Gayet, S. Pollet, S.

Hasnaoui, F. Lorente, S. Perret and B. Decenciere for their help in field work. 


\section{$338 \quad$ Funding}

339 This work was financed by grants from the local government (Ile-de-France: Sustainable 340 Development Network R2DS, No. 2012-11 to J.G.), and from the "Agence Nationale de la 341 Recherche" (No. ANR-13-PDOC-0002 to S.L.).

\section{Conflict of interest}

344 The authors declare that they have no conflict of interest.

\section{Compliance with Ethical Standards}

All experiments were carried out in strict accordance with the recommendations of the

"European Convention for the Protection of vertebrate Animals used for Experimental and

Other Scientific Purposes" and were conducted under the authorizations of the "Ministère de

350

l'éducation nationale, de l'enseignement supérieur et de la recherche" (authorization N_00093.02) and the "Direction Departementale des Services Veterinaires de Seine-etMarne" (authorization N_77-05). The authors declare no conflict of interest.

\section{References}

Amo L, Avilés JM, Parejo D, Peña A, Rodríguez J, Tomás G (2012) Sex recognition by odour and variation in the uropygial gland secretion in starlings J Anim Ecol 81:605-613

Archie EA, Theis KR (2011) Animal behaviour meets microbial ecology Anim Behav 82:425-436 doi:10.1016/j.anbehav.2011.05.029

Azimi S, Rocher V, Muller M, Moilleron R, Thevenot DR (2005) Sources, distribution and variability of hydrocarbons and metals in atmospheric deposition in an urban area (Paris, France) Sci Total Environ 337:223-239

Balthazart J, Schoffeniels E (1979) Pheromones are involved in the control of sexual-behavior in birds Naturwissenschaften 66:55-56

Balthazart J, Taziaux M (2009) The underestimated role of olfaction in avian reproduction? Behav Brain Res 200:248-259 
Baos R, Blas J, Bortolotti GR, Marchant TA, Hiraldo F (2006) Adrenocortical response to stress and thyroid hormone status in free-living nestling white storks (Ciconia ciconia) exposed to heavy metal and arsenic contamination Environ Health Perspect 114:1497

Berglund ÅM, Sturve J, Förlin L, Nyholm N (2007) Oxidative stress in pied flycatcher (Ficedula hypoleuca) nestlings from metal contaminated environments in northern Sweden Environ Res 105:330-339

Bernier UR, Allan SA, Quinn BP, Kline DL, Barnard DR, Clark GG (2008) Volatile compounds from the integument of white leghorn chickens (Gallus gallus domesticus L.): candidate attractants of ornithophilic mosquito species J Sep Sci 31:1092-1099

Blaustein AR (1981) Sexual selection and mammalian olfaction Am Nat 117:1006-1010

Bombail V et al. (2018) In search of stress odours across species: Behavioural responses of rats to faeces from chickens and rats subjected to various types of stressful events Appl Anim Behav Sci 205:216-226 doi:https://doi.org/10.1016/j.applanim.2017.10.013

Borges LMF, de Oliveira Filho JG, Ferreira LL, Louly CCB, Pickett JA, Birkett MA (2015) Identification of non-host semiochemicals for the brown dog tick, Rhipicephalus sanguineus sensu lato (Acari: Ixodidae), from tick-resistant beagles, Canis lupus familiaris Ticks and tick-borne diseases 6:676-682

Brückner A, Heethoff M (2017) A chemo-ecologists' practical guide to compositional data analysis Chemoecology 27:33-46

Burger BV, Visser R, Moses A, Le Roux M (2006) Elemental sulfur identified in urine of cheetah, Acinonyx jubatus J Chem Ecol 32:1347-1352

Burger J, Gochfeld M (2005) Effects of lead on learning in herring gulls: an avian wildlife model for neurobehavioral deficits Neurotoxicology 26:615-624

Campagna S, Mardon J, Celerier A, Bonadonna F (2012) Potential semiochemical molecules from birds: a practical and comprehensive compilation of the last 20 years studies Chem Senses 37:3-25 doi:10.1093/chemse/bjr067

Caro SP, Balthazart J, Bonadonna F (2015) The perfume of reproduction in birds: Chemosignaling in avian social life Horm Behav 68:25-42 doi:http://dx.doi.org/10.1016/j.yhbeh.2014.06.001

Castellanos P, del Olmo E, Fernández-Santos MR, Rodríguez-Estival J, Garde JJ, Mateo R (2015) Increased chromatin fragmentation and reduced acrosome integrity in spermatozoa of red deer from lead polluted sites Sci Total Environ 505:32-38

Charpentier MJ, Barthes N, Proffit M, Bessière JM, Grison C (2012) Critical thinking in the chemical ecology of mammalian communication: roadmap for future studies Funct Ecol 26:769-774

Chatelain M, Frantz A, Gasparini J, Leclaire S (2016a) Experimental exposure to trace metals affects plumage bacterial community in the feral pigeon J Avian Biol

Chatelain M, Gasparini J, Frantz A (2016b) Do trace metals select for darker birds in urban areas? An experimental exposure to lead and zinc Global change biology 22:2380-2391

Chatelain M, Gasparini J, Frantz A (2016c) Trace metals, melanin-based pigmentation and their interaction influence immune parameters in feral pigeons (Columba livia) Ecotoxicology 25:521-529

Chatelain M, Gasparini J, Jacquin L, Frantz A (2014) The adaptive function of melanin-based plumage coloration to trace metals Biol Lett 10 doi:10.1098/rsbl.2014.0164

Chatelain M, Pessato A, Frantz A, Gasparini J, Leclaire S (2017) Do trace metals influence visual signals? Effects of trace metals on iridescent and melanic feather colouration in the feral pigeon Oikos

Chilgren J, King J (1973) Thermoregulatory responses of Japanese Quail to various air temperatures and humidities Int J Biometeorol 17:29-40

Dauwe T, Bervoets L, Blust R, Eens M (2002) Tissue levels of lead in experimentally exposed zebra finches (Taeniopygia guttata) with particular attention on the use of feathers as biomonitors Arch Environ Contam Toxicol 42:88-92

De Caceres M, Jansen F, De Caceres MM (2016) Package 'indicspecies' 
De Cáceres M, Legendre P (2009) Associations between species and groups of sites: indices and statistical inference Ecology 90:3566-3574 doi:10.1890/08-1823.1

delBarco - Trillo J, Burkert B, Goodwin T, Drea C (2011) Night and day: the comparative study of strepsirrhine primates reveals socioecological and phylogenetic patterns in olfactory signals $\mathrm{J}$ Evol Biol 24:82-98

Demayo A, Taylor MC, Taylor KW, Hodson PV, Hammond PB (1982) Toxic effects of lead and lead compounds on human health, aquatic life, wildlife plants, and livestock Crit Rev Environ Sci Technol 12:257-305

Douglas AE, Dobson AJ (2013) New synthesis: animal communication mediated by microbes: fact or fantasy? J Chem Ecol 39:1149-1149

Douglas HD (2013) Colonial seabird's paralytic perfume slows lice down: An opportunity for parasitemediated selection? Int J Parasitol 43:399-407

Douglas HD, Kitaysky AS, Kitaiskaia EV (2008) Seasonal covariation in progesterone and odorant emissions among breeding crested auklets (Aethia cristatella) Horm Behav 54:325-329

Ezenwa VO, Williams AE (2014) Microbes and animal olfactory communication: where do we go from here? BioEssays 36:847-854

Ferkin M, Sorokin E, Johnston R, Lee C (1997) Attractiveness of scents varies with protein content of the diet in meadow voles Anim Behav 53:133-141

Filzmoser P, Hron K, Reimann C (2009) Principal component analysis for compositional data with outliers Environmetrics: The official journal of the International Environmetrics Society 20:621-632

Fosmire GJ (1990) Zinc toxicity Am J Clin Nutr 51:225-227

Frantz A et al. (2012) Contrasting levels of heavy metals in the feathers of urban pigeons from close habitats suggest limited movements at a restricted scale Environ Pollut 168:23-28

Gabirot M, Buatois B, Müller CT, Bonadonna F (2018) Odour of King Penguin feathers analysed using direct thermal desorption discriminates between individuals but not sexes Ibis

Gabirot M et al. (2016) Chemical labels differ between two closely related shearwater taxa J Avian Biol 47:540-551

Giraudeau M, Mateos-Gonzalez F, Cotín J, Pagani-Nuñez E, Torné-Noguera A, Senar J (2015) Metal exposure influences the melanin and carotenoid-based colorations in great tits Sci Total Environ 532:512-516

Godwin HA (2001) The biological chemistry of lead Curr Opin Chem Biol 5:223-227

Goodwin TE et al. (2016) The role of bacteria in chemical signals of elephant musth: Proximate causes and biochemical pathways. In: Schulte BA (ed) Chemical Signals in Vertebrates 13. Springer, pp 63-85

Gorissen L, Snoeijs T, Duyse EV, Eens M (2005) Heavy metal pollution affects dawn singing behaviour in a small passerine bird Oecologia 145:504-509 doi:10.1007/s00442-005-0091-7

Gorman ML, Nedwell DB, Smith RM (1974) Analysis of contents of anal scent pockets of Herpestes auropunctatus (Carnivora-Viverridae). J Zool 172:389-399

Goutte A et al. (2014) Demographic consequences of heavy metals and persistent organic pollutants in a vulnerable long-lived bird, the wandering albatross Proceedings of the Royal Society of London B: Biological Sciences 281:20133313

Grieves LA, Kelly TR, Bernards MA, MacDougall-Shackleton EA (2018) Malarial infection alters wax ester composition of preen oil in songbirds: Results of an experimental study The Auk 135:767-776 doi:10.1642/AUK-17-242.1

Hagelin JC, Jones IL (2007) Bird odors and other chemical substances: A defense mechanism or overlooked mode of intraspecific communication? Auk 124:741-761

Havlicek J, Roberts SC, Flegr J (2005) Women's preference for dominant male odour: effects of menstrual cycle and relationship status Biol Lett 1:256-259

Hirao A, Aoyama M, Sugita S (2009) The role of uropygial gland on sexual behavior in domestic chicken Gallus gallus domesticus Behav Process 80:115-120 
Jacob J, Grimmer G (1975) Gefiederlipide der ringeltaube Columba palumbus/Plumage lipids from the ring dove (Columba palumbus) Zeitschrift für Naturforschung C 30:363-368

Jacob J, Ziswiler V (1982) The uropygial gland. In: Farner DS, King JR, Parkes KC (eds) Avian biology, vol 6. Academic Press, New-York, pp 199-324

Järup L (2003) Hazards of heavy metal contamination Br Med Bull 68:167-182

Johnston RE, Bronson F (1982) Endocrine control of female mouse odors that elicit luteinizing hormone surges and attraction in males Biol Reprod 27:1174-1180

Kaya $H$, Akbulut $M$ (2015) Effects of waterborne lead exposure in mozambique tilapia: oxidative stress, osmoregulatory responses, and tissue accumulation J Aquat Anim Health 27:77-87

Kimball BA, Yamazaki K, Kohler D, Bowen RA, Muth JP, Opiekun M, Beauchamp GK (2013) Avian influenza infection alters fecal odor in mallards PloS one 8:e75411

Kirillov V, Stikhareva T, Suleimen Y, Serafimovich M, Kabanova S, Mukanov B (2017) Chemical composition of the essential oil from carnation coniferous (Dianthus acicularis Fisch. ex Ledeb) growing wild in Northern Kazakhstan Natural product research 31:117-123

Koivula MJ, Eeva T (2010) Metal-related oxidative stress in birds Environ Pollut 158:2359-2370

Krause TE, Krüger O, Kohlmeier P, Caspers BA (2012) Olfactory kin recognition in a songbird Biol Lett 8:327-329 doi:10.1098/rsbl.2011.1093

Leclaire S, Merkling T, Raynaud C, Giacinti G, Bessière JM, Hatch SA, Danchin E (2011) An individual and a sex odor signature in kittiwakes? Study of the semiochemical composition of preen secretion and preen down feathers Naturwissenschaften 98:615-624 doi:10.1016/j.yhbeh.2008.07.002

Leclaire S, Pierret P, Chatelain M, Gasparini J (2014a) Feather bacterial load affects plumage condition, iridescent color, and investment in preening in pigeons Behav Ecol:aru109

Leclaire S, Strandh M, Mardon J, Westerdahl H, Bonadonna F Odour-based discrimination of similarity at the major histocompatibility complex in birds. In: Proc. R. Soc. B, 2017. vol 1846. The Royal Society, p 20162466

Leclaire $S$ et al. (2014b) Preen secretions encode information on MHC similarity in certain sex-dyads in a monogamous seabird Sci Reports 4

Li Q et al. (2013) Synchronous evolution of an odor biosynthesis pathway and behavioral response Curr Biol 23:11-20

López-Rull I, Pagán I, Macías Garcia C (2010) Cosmetic enhancement of signal coloration: experimental evidence in the house finch Behav Ecol 21:781-787 doi:10.1093/beheco/arq053

Mardon J, Saunders JR, Bonadonna F (2011) From preen secretions to plumage: the chemical trajectory of blue petrels' Halobaena caerulea social scent J Avian Biol 42:29-38

Martin-Vivaldi M, Pena A, Manuel Peralta-Sanchez J, Sanchez L, Ananou S, Ruiz-Rodriguez M, Jose Soler J (2010) Antimicrobial chemicals in hoopoe preen secretions are produced by symbiotic bacteria Proc R Soc B 277:123-130 doi:10.1098/rspb.2009.1377

Martín J, López P (2006) Links between male quality, male chemical signals, and female mate choice in Iberian rock lizards Funct Ecol 20:1087-1096

McGraw KJ, Mackillop EA, Dale J, Hauber ME (2002) Different colors reveal different information: how nutritional stress affects the expression of melanin-and structurally based ornamental plumage J Exp Biol 205:3747-3755

Meillère A, Brischoux F, Bustamante P, Michaud B, Parenteau C, Marciau C, Angelier F (2016) Corticosterone levels in relation to trace element contamination along an urbanization gradient in the common blackbird (Turdus merula) Sci Total Environ 566:93-101

Montalti D, Gutiérrez AM, Reboredo G, Salibián A (2005) The chemical composition of the uropygial gland secretion of rock dove Columba livia Comp Biochem Physiol, A: Comp Physiol 140:275279

Moreno - Rueda G (2015) Body - mass - dependent trade - off between immune response and uropygial gland size in house sparrows Passer domesticus J Avian Biol 46:40-45

Moreno - Rueda G (2017) Preen oil and bird fitness: A critical review of the evidence Biological Reviews 92:2131-2143 
Moyer BR, Rock AN, Clayton DH (2003) Experimental test of the importance of preen oil in rock doves (Columba livia) Auk 120:490-496

Nriagu JO (1979) Global inventory of natural and anthropogenic emissions of trace metals to the atmosphere Nature 279:409-411

Nriagu JO (1996) A history of global metal pollution Science 272:223

Oksanen J et al. (2013) Package 'vegan' Community ecology package, version 2

Oteiza PI, Olin KL, Fraga CG, Keen CL (1995) Zinc deficiency causes oxidative damage to proteins, lipids and DNA in rat testes J Nutr 125:823

Pap PL, Vágási Cl, Bărbos L, Marton A (2013) Chronic coccidian infestation compromises flight feather quality in house sparrows Passer domesticus Biol J Linn Soc 108:414-428

Papanikolaou NC, Hatzidaki EG, Belivanis S, Tzanakakis GN, Tsatsakis AM (2005) Lead toxicity update. A brief review Medical science monitor 11:RA329-RA336

Penn D, Potts WK (1998) Chemical signals and parasite-mediated sexual selection Trends Ecol Evol 13:391-396

Piault R, Gasparini J, Bize P, Paulet M, McGraw KJ, Roulin A (2008) Experimental support for the makeup hypothesis in nestling tawny owls (Strix aluco) Behav Ecol 19:703-709

Prasad AS (2003) Zinc deficiency: has been known of for 40 years but ignored by global health organisations BMJ: British Medical Journal 326:409

R Core Team (2017) R: A language and environment for statistical computing. R Foundation for Statistical Computing, Vienna, Austria

Raymer J, Wiesler D, Novotny M, Asa C, Seal U, Mech L (1986) Chemical scent constituents in urine of wolf (Canis lupus) and their dependence on reproductive hormones J Chem Ecol 12:297-314

Roux KE, Marra PP (2007) The presence and impact of environmental lead in passerine birds along an urban to rural land use gradient Arch Environ Contam Toxicol 53:261-268

Scheuhammer AM, Meyer MW, Sandheinrich MB, Murray MW (2007) Effects of environmental methylmercury on the health of wild birds, mammals, and fish AMBIO: a Journal of the Human Environment 36:12-19

Schulz S, Dickschat JS (2007) Bacterial volatiles: the smell of small organisms Nat Prod Rep 24:814842

Smith S, Burden H, Persad R, Whittington K, de Lacy Costello B, Ratcliffe NM, Probert C (2008) A comparative study of the analysis of human urine headspace using gas chromatographymass spectrometry Journal of breath research 2:037022

Snoeijs T, Dauwe T, Pinxten R, Darras VM, Arckens L, Eens M (2005) The combined effect of lead exposure and high or low dietary calcium on health and immunocompetence in the zebra finch (Taeniopygia guttata) Environ Pollut 134:123-132

Snoeijs T, Dauwe T, Pinxten R, Vandesande F, Eens M (2004) Heavy metal exposure affects the humoral immune response in a free-living small songbird, the great tit (Parus major) Arch Environ Contam Toxicol 46:399-404

Soini HA, Schrock SE, Bruce KE, Wiesler D, Ketterson ED, Novotny MV (2007) Seasonal variation in volatile compound profiles of preen gland secretions of the dark-eyed junco (Junco hyemalis) J Chem Ecol 33:183-198 doi:10.1007/s10886-006-9210-0

Stefanidou M, Maravelias C, Dona A, Spiliopoulou C (2006) Zinc: a multipurpose trace element Arch Toxicol 80:1

Tainer JA, Roberts VA, Getzoff ED (1992) Protein metal-binding sites Curr Opin Biotechnol 3:378-387 doi:https://doi.org/10.1016/0958-1669(92)90166-G

Tchounwou PB, Yedjou CG, Patlolla AK, Sutton DJ (2012) Heavy metal toxicity and the environment. In: Molecular, clinical and environmental toxicology. Springer, pp 133-164

Thomas RH, Price ER, Seewagen CL, Mackenzie SA, Bernards MA, Guglielmo CG (2010) Use of TLC - FID and GC - MS/FID to examine the effects of migratory state, diet and captivity on preen wax composition in White - throated Sparrows Zonotrichia albicollis Ibis 152:782-792

Troïanowski M, Mondy N, Dumet A, Arcanjo C, Lengagne T (2017) Effects of traffic noise on tree frog stress levels, immunity, and color signaling Conserv Biol 
Vallverdú-Coll Nr, Ortiz-Santaliestra ME, Mougeot Fo, Vidal D, Mateo R (2015) Sublethal Pb exposure produces season-dependent effects on immune response, oxidative balance and investment in carotenoid-based coloration in red-legged partridges Environ Sci Technol 49:3839-3850

von Schantz T, Bensch S, Grahn M, Hasselquist D, Wittzell H (1999) Good genes, oxidative stress and condition-dependent sexual signals Proceedings of the Royal Society of London B: Biological Sciences 266:1-12

Wallraff HG (2005) Avian navigation: pigeon homing as a paradigm. Springer Science \& Business Media,

Warton DI, Wright ST, Wang Y (2012) Distance - based multivariate analyses confound location and dispersion effects Methods in Ecology and Evolution 3:89-101

Whelan RJ, Levin TC, Owen JC, Garvin MC (2010) Short-chain carboxylic acids from gray catbird (Dumetella carolinensis) uropygial secretions vary with testosterone levels and photoperiod Comparative Biochemistry and Physiology Part B: Biochemistry and Molecular Biology 156:183-188

Whittaker DJ, Rosvall KA, Slowinski SP, Soini HA, Novotny MV, Ketterson ED (2017) Songbird chemical signals reflect uropygial gland androgen sensitivity and predict aggression: implications for the role of the periphery in chemosignaling Journal of Comparative Physiology A:1-11

Whittaker DJ, Rosvall KA, Slowinski SP, Soini HA, Novotny MV, Ketterson ED (2018) Songbird chemical signals reflect uropygial gland androgen sensitivity and predict aggression: Implications for the role of the periphery in chemosignaling Journal of Comparative Physiology A 204:5-15

Whittaker DJ, Soini HA, Atwell JW, Hollars C, Novotny MV, Ketterson ED (2010) Songbird chemosignals: volatile compounds in preen gland secretions vary among individuals, sexes, and populations Behav Ecol 21:608-614 doi:10.1093/beheco/arq033

Whittaker DJ, Theis KR (2016) Bacterial communities associated with junco preen glands: Preliminary ramifications for chemical signaling. In: Schulte BA, Goodwin TE, Ferkin MH (eds) Chemical Signals in Vertebrates 13. Springer International Publishing, Cham, pp 105-117. doi:10.1007/978-3-319-22026-0_8

Wyatt TD (2014) Pheromones and animal behavior: chemical signals and signatures. Cambridge University Press,

Zahavi A, Zahavi A (1999) The handicap principle: a missing piece of Darwin's puzzle. Oxford University Press,

Zhang J-X, Sun L, Zuo M (2009) Uropygial gland volatiles may code for olfactory information about sex, individual, and species in Bengalese finches Lonchura striata Curr Zool 55:357-365

Zhang JX, Wei W, Zhang JH, Yang WH (2010) Uropygial gland-secreted alkanols contribute to olfactory sex signals in budgerigars Chem Senses 35:375-382 doi:10.1093/chemse/bjq025 
Figure captions

610 Figure 1: Representative chromatogram of feather volatiles in captive pigeons. Letters refer 611 to compounds listed in table 1.

612

613 Figure 2: Partial unconstrained distance-based redundancy analysis plot showing separation 614 between pigeons by zinc supplementation. The effect of the period when the samples were ran 615 on the GCMS was partialled out to better show separation.

616

617 Figure 3: Mean \pm SE proportion of the four chemical compounds that varied with zinc 618 exposure in zinc-supplemented birds and non zinc-supplemented birds. $\mathrm{P}$ values were 619 calculated using a mixed model with date of sampling as a random effect and analyses time 620 period as covariate.

621

622 Figure 4: Robust principal component analysis plot showing separation between pigeons by 623 zinc supplementation. Vectors representing chemical compounds with high loading on axis 2 624 are highlighted.

625

626 
Table 1: Chemical compounds putatively identified in the feathers of feral pigeons.

\begin{tabular}{|c|c|c|c|c|}
\hline Name & $\begin{array}{l}\text { Letter } \\
\text { (see } \\
\text { figure } \\
\text { 1) }\end{array}$ & $\begin{array}{l}\text { Retention } \\
\text { index } \\
\text { calculated }\end{array}$ & $\begin{array}{l}\text { Detected in } \\
\text { preen } \\
\text { secretions }\end{array}$ & $\begin{array}{c}\text { Detected on the } \\
\text { plumage of } \\
\text { wild Parisian } \\
\text { pigeons }\end{array}$ \\
\hline \multicolumn{5}{|l|}{ Ketones } \\
\hline Hexan-3-one & $\mathrm{a}$ & n.d. & & $\mathrm{x}$ \\
\hline 6-methyl-5-Hepten-2-one & $\mathrm{b}$ & 982 & & $\mathrm{x}$ \\
\hline \multicolumn{5}{|l|}{ Aldehydes } \\
\hline Hexanal & $\mathrm{c}$ & n.d. & & $\mathrm{x}$ \\
\hline Heptanal & $\mathrm{d}$ & 896 & & $\mathrm{x}$ \\
\hline Nonanal & $\mathrm{e}$ & 1101 & $\mathrm{x}$ & $\mathrm{x}$ \\
\hline Decanal & & 1202 & $\mathrm{x}$ & $\mathrm{x}$ \\
\hline \multicolumn{5}{|l|}{ Alkanes } \\
\hline Octane & $\mathrm{f}$ & n.d. & & $\mathrm{x}$ \\
\hline 2, 4-dimethyl-Heptane & & 817 & & $\mathrm{x}$ \\
\hline Nonane & $\mathrm{g}$ & 899 & & $\mathrm{x}$ \\
\hline Branched alkane \#1 & $\mathrm{h}$ & 1060 & & $\mathrm{x}$ \\
\hline Branched alkane \#2 & o & 1065 & & $\mathrm{x}$ \\
\hline Branched alkane \#3 & $\mathrm{i}$ & 1104 & & $\mathrm{x}$ \\
\hline Branched alkane \#4 & & 1109 & & $\mathrm{x}$ \\
\hline Dodecane & & 1200 & & $\mathrm{x}$ \\
\hline
\end{tabular}




\begin{tabular}{|c|c|c|c|c|}
\hline Branched alkane \#5 & & 1277 & & $\mathrm{x}$ \\
\hline Branched alkane \#6 & $\mathrm{j}$ & 1283 & & $\mathrm{x}$ \\
\hline Branched alkane \#7 & & 1305 & & $\mathrm{x}$ \\
\hline Branched alkane \#8 & & 1322 & & $\mathrm{x}$ \\
\hline Branched alkane \#9 & $\mathrm{k}$ & 1329 & & $\mathrm{x}$ \\
\hline Branched alkane \#10 & & 1337 & & $\mathrm{x}$ \\
\hline Branched alkane \#11 & & 1345 & & $\mathrm{x}$ \\
\hline Branched alkane \#12 & & 1348 & & $\mathrm{x}$ \\
\hline Tridecane & & 1300 & & $\mathrm{x}$ \\
\hline Pentadecane & & 1500 & & $\mathrm{x}$ \\
\hline \multicolumn{5}{|l|}{ Alcohols } \\
\hline Pentanol & & n.d. & & $\mathrm{x}$ \\
\hline 2-butoxy-Ethanol & & 903 & & $\mathrm{x}$ \\
\hline 1-butoxy-2-Propanol & & 940 & & $\mathrm{x}$ \\
\hline 1-Octen-3-ol & & 978 & & $\mathrm{x}$ \\
\hline 2-ethyl-Hexan-1-ol & 1 & 1028 & & $\mathrm{x}$ \\
\hline 2, 6-dimethyl-7-Octen-2-ol & & 1071 & & $\mathrm{x}$ \\
\hline \multicolumn{5}{|l|}{ Esters } \\
\hline Butanoic acid, methyl ester & & n.d. & & $\mathrm{x}$ \\
\hline Propanoic acid, propyl ester & & 804 & & \\
\hline Acetic acid, butyl ester & $\mathrm{m}$ & 809 & & $\mathrm{x}$ \\
\hline Hexanoic acid, methyl ester & & 922 & & $\mathrm{x}$ \\
\hline Hydroxy ester \#1 & $\mathrm{n}$ & 1357 & $\mathrm{x}$ & $\mathrm{x}$ \\
\hline Hydroxy ester \#2 & o & 1376 & $\mathrm{X}$ & $\mathrm{X}$ \\
\hline
\end{tabular}




\begin{tabular}{|c|c|c|c|c|}
\hline Fatty acids & & & & \\
\hline Nonanoic acid & & 1273 & & $\mathrm{x}$ \\
\hline \multicolumn{5}{|l|}{ Unknown } \\
\hline Unknown \#1 & $\mathrm{p}$ & 884 & & $\mathrm{X}$ \\
\hline Unknown \#2 & $q$ & 910 & & \\
\hline Unknown \#4 & & 1143 & & \\
\hline Unknown \#5 & & 1232 & & \\
\hline Unknown \#6 & $\mathrm{r}$ & 1295 & & \\
\hline Unknown \#7 & & 1307 & & $\mathrm{x}$ \\
\hline Unknown \#8 & & 1316 & & \\
\hline $\begin{array}{l}2,2,4,6,6- \\
\text { pentamethylheptane + } \\
\text { hexanoic acid }^{\text {a }}\end{array}$ & $\mathrm{s}$ & 993 & $\mathrm{X}$ & $\mathrm{X}$ \\
\hline
\end{tabular}

n.d.: not determined

${ }^{a}$ : These two compounds were eluted together. 